\title{
Frameshift Mutation
}

National Cancer Institute

\section{Source}

National Cancer Institute. Frameshift Mutation. NCI Thesaurus. Code C17354.

A mutation occurring within the protein-coding region of a gene which results in a shift in the reading frame of the encoded protein. Frameshift mutations often result in the premature truncation of a gene product. 